\title{
Variations of Source Composition and Melting Degrees of Olivine-Phyric Rocks from Kamchatsky Mys: Results of Geochemical Modeling of Trace Element Contents in Melts
}

\author{
N. Nekrylov ${ }^{a, b}, *$, A. A. Korneeva ${ }^{b, c}$, D. P. Savelyev ${ }^{d}$, and T. N. Antsiferova ${ }^{a, e}$ \\ ${ }^{a}$ Fersman Mineralogical Museum, Russian Academy of Sciences, Moscow, Russia \\ ${ }^{b}$ Institute of Experimental Mineralogy, Russian Academy of Sciences, Chernogolovka, Moscow oblast, Russia \\ ${ }^{c}$ Moscow State University, Moscow, Russia \\ ${ }^{d}$ Institute of Volcanology and Seismology, Far Eastern Branch, Russian Academy of Sciences, \\ Petropavlovsk-Kamchatsky, Russia \\ ${ }^{e}$ Institute of Geology of Ore Deposits, Petrography, Mineralogy, and Geochemistry, \\ Russian Academy of Sciences, Moscow, Russia \\ *e-mail: nekrilov.n@gmail.com
}

Received March 17, 2020; revised April 25, 2020; accepted May 21, 2020

\begin{abstract}
We conducted the geochemical modeling of trace element contents for primary melts of olivinephyric rocks from Kamchatsky Mys. This modeling reveals substantial chemical heterogeneity of their source while the average source composition is close to the enriched DMM (E-DMM). The average estimation of the melting degree is in the range from $9.1 \pm 3.8 \%$ for the model of modal batch melting to $15.4 \pm 5.2 \%$ for the model of accumulated fractional melting, which is slightly higher than the estimation for primitive mid-ocean ridge basalt $(\mathrm{MORB})$ glasses $(7.4 \pm 2.2 \%$ and $12.5 \pm 3.8 \%$ respectively $)$. It is in a good agreement with high melting degrees estimated earlier for other rocks of the Kamchatsky Mys ophiolites. Low pressure of mantle melting caused by the elevated speed of decompression relative to the average MORB could explain elevated melting degrees estimated for Kamhcatsky Mys ophiolites as well as their characteristic Sr-anomalies and sulfide saturation on the earliest stages of magmatic evolution.
\end{abstract}

Keywords: Kamchatsky Mys, mantle melting, olivine, melt inclusions

DOI: $10.1134 / \mathrm{S} 0869591121010045$

\section{INTRODUCTION}

Kamchatsky Mys peninsula occupies a unique geological position on the triple junction of the North American, Eurasian, and Pacific plates (e.g., Avdeiko et al., 2007; Konstantinovskaia, 2001). A Cretaceous ophiolite complex located on this peninsula draw researches' attention due to its unusual geochemical and petrological features (Batanova et al., 2014; Khotin and Shapiro, 2006; Portnyagin et al., 2005, 2009, 2008). These features include high estimated degrees of mantle melting and different geochemical markers in the composition of whole-rocks and reconstructed melts, which allowed linking the origin of the ophiolite complex with the proto-Hawaiian plume (Batanova et al., 2014; Portnyagin et al., 2009, 2008).

Volcanic rocks with primitive olivine (up to $F o_{90}$ ) were found in the ophiolite complex of Kamchatsky Mys only in 2012 (Savelyev, 2014). They are represented by plagioclase-olivine-phyric basalts, whose bulk composition corresponds to picrites due to the abundance of cumulus olivine, up to 50-60 vol \%. All of their key geochemical features and reconstructed crystallization conditions correspond to typical midocean ridge basalts (MORB). An early manifestation of sulfide-silicate saturation was documented in these rocks among other features, which makes them the perfect object for studying the generation and early evolution of oceanic magmas (Korneeva et al., 2020; Savelyev et al., 2018).

Well-preserved olivine allowed us earlier to reconstruct the composition of parental melts of these plagioclase-olivine-phyric basalts on the base of melt inclusions study (Korneeva et al., 2020). The most interesting features of these parental melts are wide variations of highly incompatible trace elements and relatively low contents of moderately incompatible trace elements (e.g., HREE) in comparison with primitive MORB glasses (Fig. 1). Trace elements in the olivine from these rocks indicate that their source mineralogical composition corresponds to peridotites (Korneeva et al., 2020), which is typical for the MORB mantle. This fact allows us to suggest that unusual patterns of trace elements distribution in reconstructed 


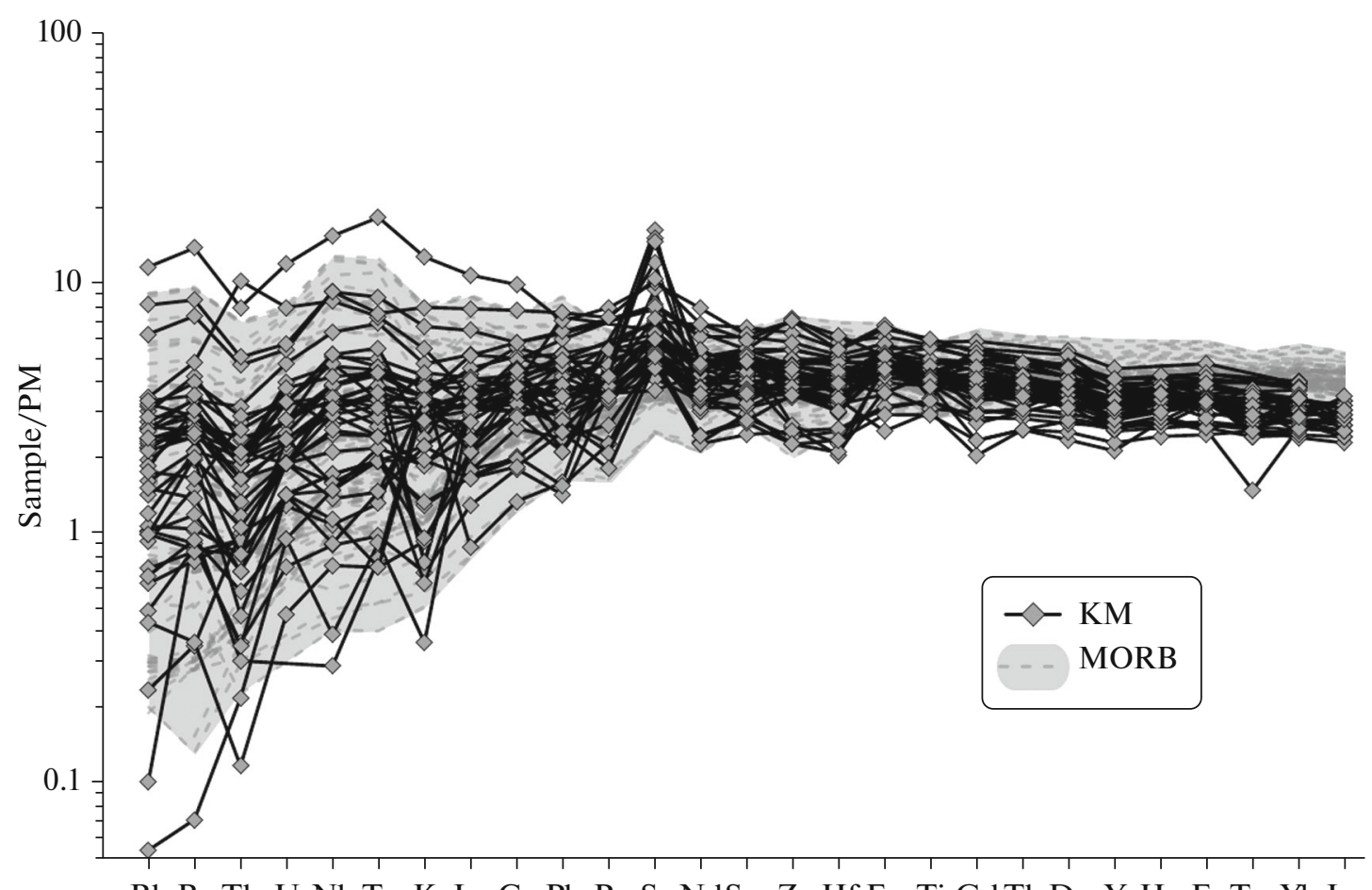

$\mathrm{Rb}$ Ba Th U Nb Ta K La Ce Pb Pr Sr NdSm Zr Hf Eu Ti Gd Tb Dy Y Ho Er Tm Yb Lu

Fig. 1. Trace-element distribution patterns of primary melts of olivine-phyric rocks from Kamchatsky Mys in comparison with primitive MORB glasses (Jenner and O'Neill, 2012) recalculated to be in equilibrium with $F o_{90}$ by simulation of reverse olivine crystallization (Danyushevsky and Plechov, 2011).

melts are linked to chemical heterogeneity of the source and melting degrees.

Equations that link the contents of trace elements in melts with their contents in source and melting degrees are well known (e.g., Gast, 1968; Liang and Liu, 2016; Shaw, 1970; Zou, 1998) and allow us to model a wide range of melting processes for sources of different composition. However, researchers tend to select a particular melting model (e.g. Mironov and Portnyagin, 2018; Popov et al., 2017; Portnyagin et al., 2007a, 2007b; Volynets et al., 2010) and/or source composition (e.g., Krasnova et al, 2013; Liang and Liu, 2016; Nekrylov et al., 2018; Stolper and Newman, 1994; Tobelko et al., 2019) for their modeling and estimations of mantle melting parameters. This approach is frequently justified by the fact that the chosen model and source composition allows them to obtain a highquality approximation of their natural sample compositions.

In this study we made an attempt to estimate the possible range of melting degrees and source compositions for individual melts of olivine-phyric rocks of Kamchatsky Mys (Korneeva et al., 2020) using different melting mechanisms and variable source compositions for modeling. We showed that trace elements in the majority of these melts can be equally well approximated by models of batch and accumulated fractional melting, while the estimated melting parameters for them can significantly vary depending on the chosen melting mechanism.

\section{PARAMETERS OF MODELING}

There are two "boundary" models of equilibrium melting that link the composition of the melting material with the resulting melt: model of accumulative fractional melting (AFM) (1) and model of batch melting (BM) (2).

$$
\begin{gathered}
\frac{C_{i}^{l}}{C_{i}^{s}}=\frac{1-(1-F)^{\frac{1}{D_{i}}}}{F}, \\
\frac{C_{i}^{l}}{C_{i}^{s}}=\frac{1}{D_{i}+F\left(1-D_{i}\right)},
\end{gathered}
$$

where $C_{i}^{l}$ is the concentration of the element in the resulting melt, $C_{i}^{s}$ is the concentration of the element in the starting material (source), $D_{i}$ is the partition coefficient of the element between the melt and source, and $F$ is the melting degree.

Both these models describe simplified mechanisms of mantle melting and do not account for such crucial parameters of the magmatic system as volume porosity and the percent of melt retained in the source. However, accounting for additional parameters would lead 
to models in which the resulting melt would be in between the resulting melts predicted by BM and AFM models (Zou, 1998). The process of melting could also be disequilibrium in case of the high difference between rates of melting and diffusive re-equilibration of the melt with the solid residue. Modeling of the disequilibrium degree for MORB residual peridotites has shown that melting models corrected for this effect still give the results in between of BM and AFM models for most samples (Liang and Liu, 2016), which allow us to neglect this effect. Consequently, we can use simple BM and AFM models to calculate the "boundary" values of melting degrees and source compositions based on primary melts of olivinephyric rocks from Kamchatsky Mys.

To estimate the compositions of the primary melts of olivine-phyric rocks from Kamchatsky Mys we assumed that they were in equilibrium with typical olivine of MORB mantle peridotites, $F_{90}$ (e.g., Dick, 1989). We then simulated reverse olivine crystallization using Petrolog3 software (Danyushevsky and Plechov, 2011) for the parental melts of these rocks (Korneeva et al., 2020) until they were in equilibrium with the $\mathrm{Fo}_{90}$. Trace elements in melts were accounted as completely incompatible to olivine at this stage of our calculations. The calculated compositions of primary melts are shown in the Supplementary: ESM_1.xls. ${ }^{1}$

We used several assumptions to model the process of mantle melting: (1) the source had an average modal composition close to the depleted MORB mantle (DMM) (Workman and Hart, 2005): 57\% Ol, 28\% $O p x, 13 \% C p x, 2 \% S p l ;(2)$ bulk source-melt partition coefficients for trace elements $\left(C_{0}^{i}\right)$ (for $\mathrm{Rb}, \mathrm{Ba}, \mathrm{U}$, $\mathrm{Nb}, \mathrm{Ta}, \mathrm{La}, \mathrm{Ce}, \mathrm{Pb}, \mathrm{Pr}, \mathrm{Nd}, \mathrm{Zr}, \mathrm{Hf}, \mathrm{Sm}, \mathrm{Eu}, \mathrm{Ti}, \mathrm{Gd}$, $\mathrm{Tb}$, Dy, Ho, Y, Er, Yb, and Lu) also correspond to average values for DMM (Workman and Hart, 2005);

(3) $C_{0}^{i}$ does not change during the melting process (modal melting); (4) trace elements contents in the source could have varied from typical for depleted DMM (D-DMM) to the primitive mantle (PM) (DDMM, DMM, and enriched DMM (E-DMM) are from (Workman and Hart, 2005), PM is from (McDonough and Sun, 1995)). On the base of these assumptions, we calculated the range of trace elements in sources from D-DMM to PM with a step of 0.1 (for example, 0.9 D-DMM + 0.1 A-DMM, 0.8 D-DMM +0.2 A-DMM, etc.) and the composition of resulting

\footnotetext{
${ }^{1}$ Composition of primary melts of olivine-phyric rocks from Kamchatsky Mys and the detailed results of geochemical modeling are shown in following tables at https://elibrary.ru/ and http://link.springer.com/ as a supplementary for Russian and English versions of the article, respectively:

ESM_1.xls-Composition of primary melts of olivine-phyric rocks from Kamchatsky Mys;

ESM 2.xls-Results of mantle melting modeling from 0.5 to $50 \%$ for sources ranging from D-DMM to PM;

ESM_3.xls-Batch and partial melting modeling for individual primary melt compositions.
}

melts for each of them at melting degrees varying from 0.5 to $50 \%$ using BM and AFM models (Supplementary: ESM_2.xls). We could find the best approximation for each composition of primary melts (Supplementary: ESM_1.xls) using the least-squared method among the resulting melts obtained by BM and AFM modeling for each source. This method also allows us to define which source composition gives the resulting melt with the best approximation of the composition of the primary melt. On this step of our modeling, we did not account for the contents of $\mathrm{Sr}$ and $\mathrm{Th}$ in primary melts of the olivine-phyric rocks from Kamchatsky Mys because most of them are characterized by positive $\mathrm{Sr}$ and negative $\mathrm{Th}$ anomalies of unclear genesis (Korneeva et al., 2020). As an illustration of our modeling we show several best fits for primary melts D-1456-Mt1-gr5 and D-1456-Mt1-gr6 for seven source compositions from D-DMM to PM (with the step of 0.5 ) and the best approximation for all sources (Fig. 2).

The results of the modeling for the primary melts of olivine-phyric rocks from Kamchatsky Mys are shown in Table 1 and Supplementary: ESM_3.xls.

\section{RESULTS}

The results of our modeling show that BM and AFM models allow us to reproduce the composition of primary melts of olivine-phyric rocks from Kamchatsky Mys with the same on average least sum of squares (Fig. 3). This conclusion is applicable to both high- and low-quality approximation (low and high least sum of squares, respectively). The fact that some of the melt compositions cannot be approximated within our model could be explained by substantial differences between the modeled and actual source composition (chemical or mineralogical) or by an analytical error during measurements of melt inclusions. Only 37 out of 46 reconstructed primary melt compositions could be satisfactorily approximated by either the BM or AMF model and only they are included in Table 1 and discussed further. A satisfactory level of approximation was determined by subjective comparison of trace element distribution spectra of the model and primary melts because we cannot set an objective level of the least sum of squares.

According to the BM model, primary melts of olivine-phyric rocks from Kamchatsky Mys should have been produced by $2.5-18.5 \%$ of the melting of sources, whose composition varied from D-DMM to $0.5 \mathrm{E}-\mathrm{DMM}+0.5 \mathrm{PM}$. The AFM model predicts a higher melting degree and higher enrichment of sources, from 5.5 to $29 \%$ and from 0.5 D-DMM + $0.5 \mathrm{~A}-\mathrm{DMM}$ to PM, respectively. Estimations of melting degrees obtained by these models show a clear positive correlation $\left(R^{2}=0.96\right)$, while the correlation of source compositions is weaker $\left(R^{2}=0.74\right)$ (Fig. 4). Average melting degrees predicted by BM and AFM 


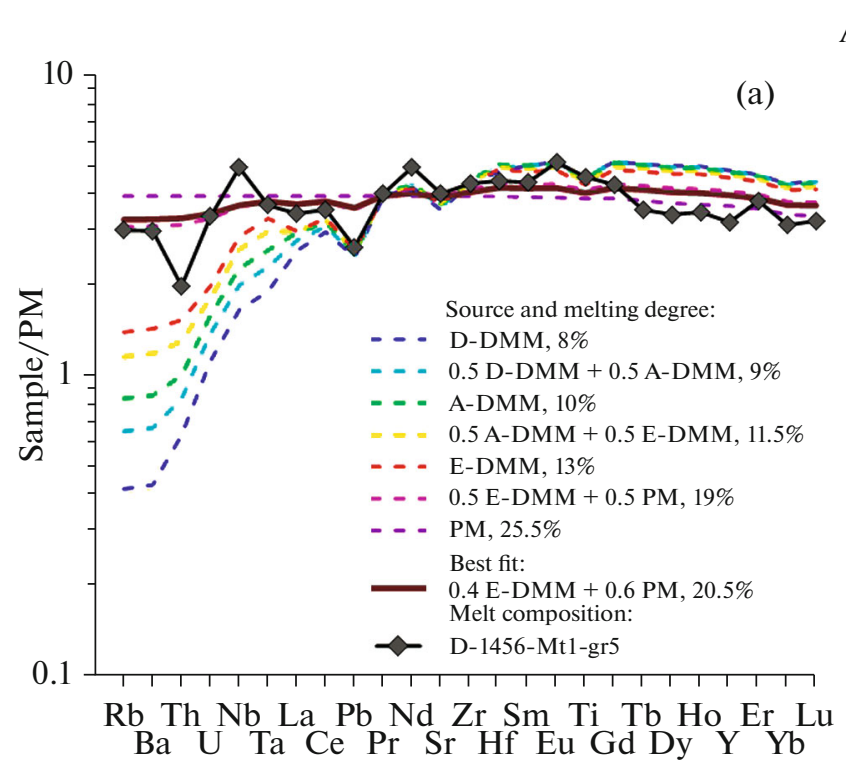

AFM:
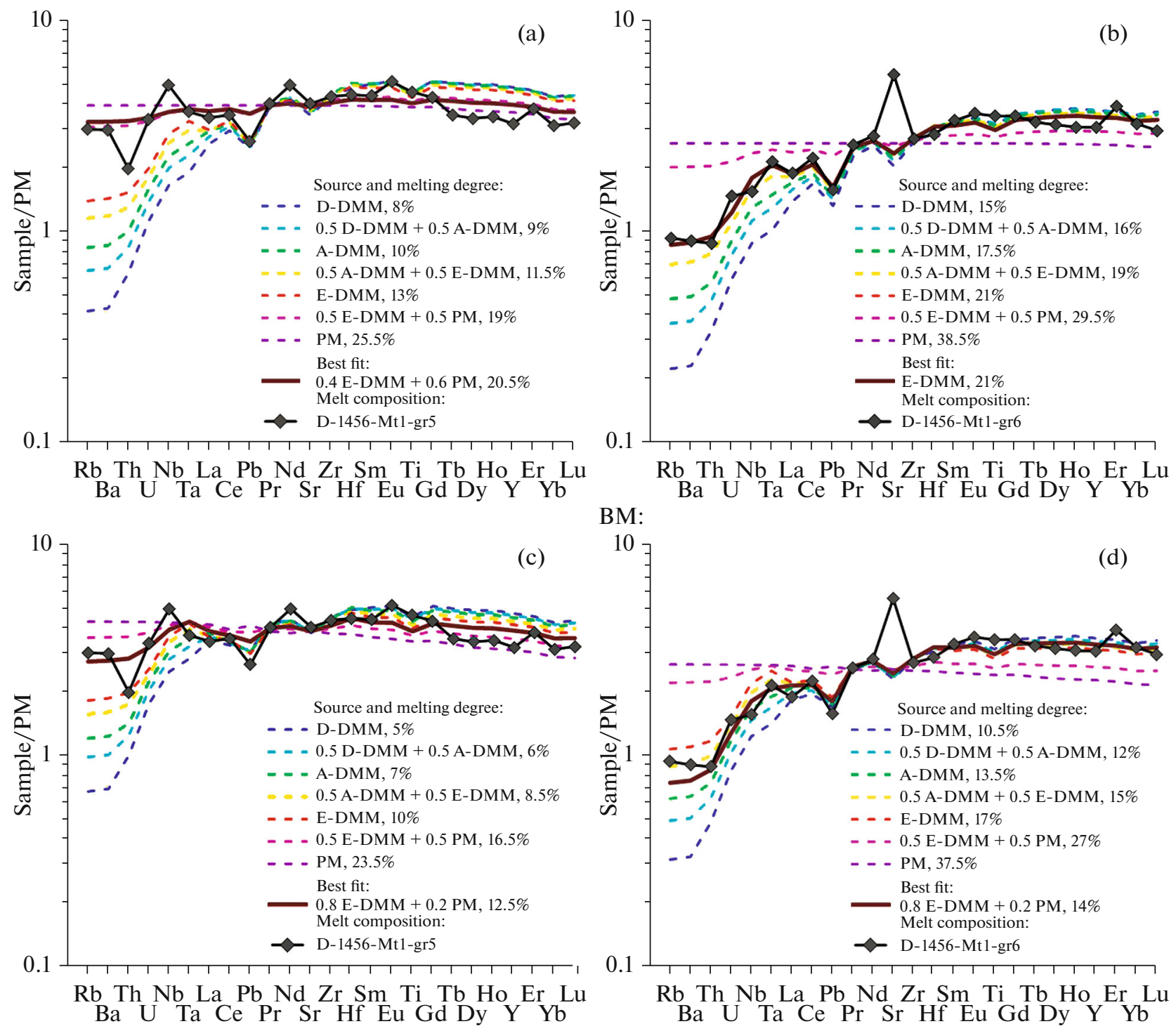

Fig. 2. The example of source composition and melting degree calculations for -1456-Mt1-gr5 and D-1456-Mt1-gr6 primary melt compositions (Supplementary: ESM_1.xls) using AFM and BM models. Dashed lines denote the best fits for several source compositions from D-DMM to PM.

models are $9.1 \pm 3.8 \%$ and $15.4 \pm 5.2 \%$, respectively, while average source compositions are $0.5 \mathrm{~A}-\mathrm{DMM}+$ 0.5 E-DMM and 0.9 E-DMM + 0.1 PM (Fig. 4).

We performed similar modeling for the set of primitive (Mg\# > $62 \mathrm{~mol} \%)$ MORB glasses published by Jenner and O'Neill (2012) to have a reference point for our data. A satisfactory approximation was obtained for 67 of 79 of these primitive glasses recalculated to equilibrium with $\mathrm{Fo}_{90}$. The AFM model provides better approximation for the majority of them: 44 vs. 23 (Fig. 3). The average source composition and melting degree obtained by the AFM model are $0.8 \mathrm{~A}-\mathrm{DMM}+$ $0.2 \mathrm{E}-\mathrm{DMM}$ and $12.5 \pm 3.8 \%$, by the $\mathrm{BM}$ model are $0.4 \mathrm{D}-\mathrm{DMM}+0.6 \mathrm{~A}-\mathrm{DMM}$ and $7.4 \pm 2.2 \%$, respectively (Fig. 4).

\section{DISCUSSION}

\section{The Influence of Melt Reconstruction on the Results of Modeling}

Primary melts of olivine-phyric rocks from Kamchatsky Mys, which we used for our modeling, were reconstructed on the base of their parental melts (Korneeva et al., 2020). These parental melts in their turn were reconstructed on the base of the composition of homogenized melt inclusions in olivine. The initial content of $\mathrm{Fe}$ in melts $\left(\mathrm{FeO}_{\mathrm{i}}\right)$ was one of the major parameters in that reconstruction. Melt inclusions re-equilibrate with their host-olivine during post-entrapment cooling, which leads to a disproportionate loss of Fe (relatively to $\mathrm{Mg}$ ) via diffusion also 


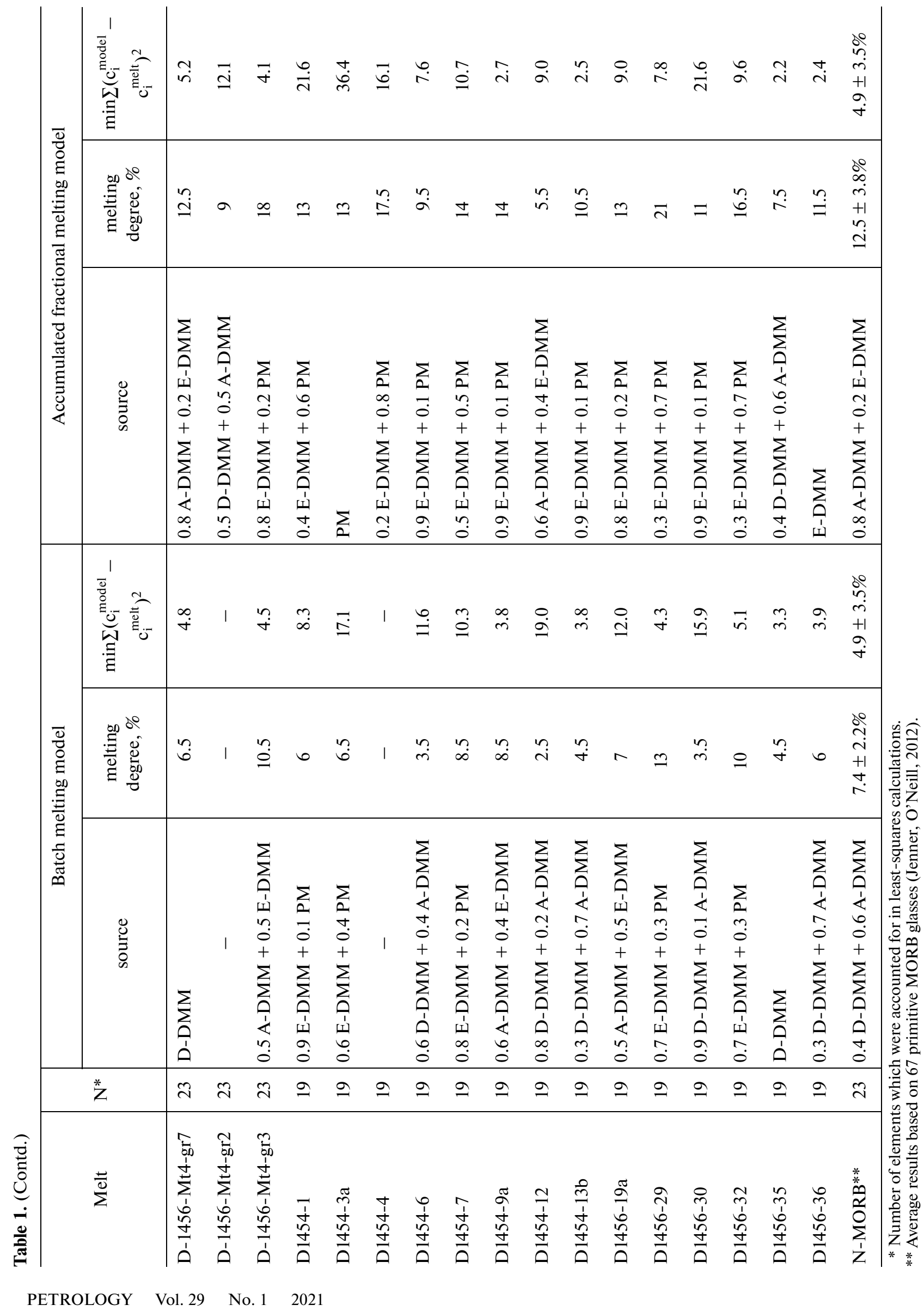




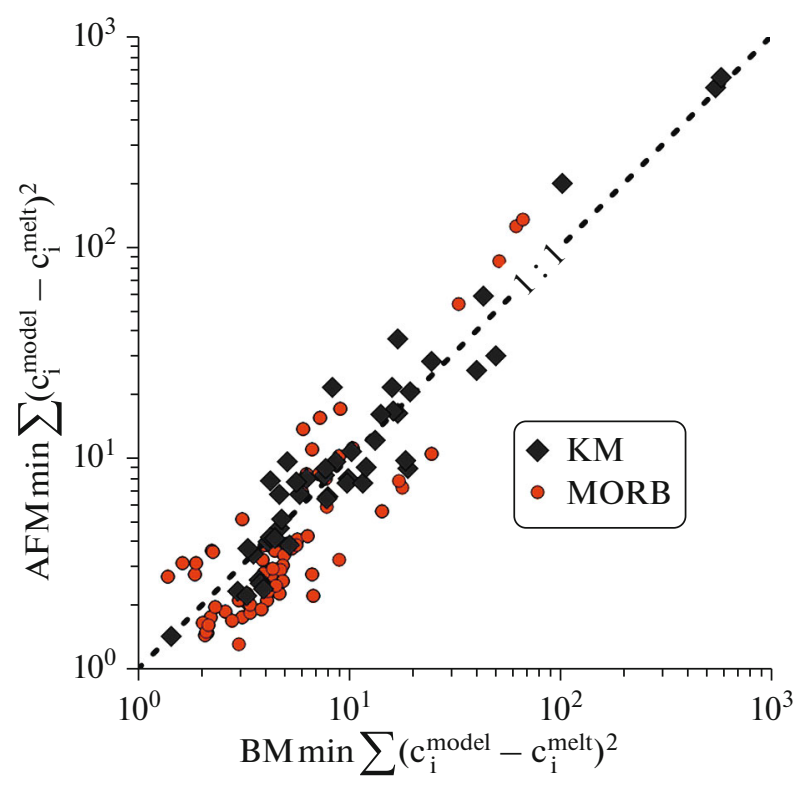

Fig. 3. The comparison of least-squares sums between the best fit model melts (AFM and BM) and primary melts of the olivine-phyric rocks of Kamchatsky Mys and MORB (Jenner, O’Neill, 2012).

known as Fe-loss (Danyushevsky et al., 2000). Errors in the estimated $\mathrm{FeO}_{\mathrm{i}}$ significantly affect the resulting composition of melts and their estimated crystallization conditions.

The average FeOi for parental melts of olivinephyric rocks from Kamchatsky Mys was estimated to be 7.93 wt \% (Korneeva et al., 2020), however, actual values of this parameter could significantly differ from that. Alternative approaches to $\mathrm{FeO}_{\mathrm{i}}$ reconstruction can give results that differ up to $1 \mathrm{wt} \%$ from the estimated value. To estimate the influence of possible errors on our results, we repeated all calculations from the reconstruction of parental melts to melting parameters for $\mathrm{FeO}_{\mathrm{i}}$ corresponding to 6.93 and 8.93 wt \%. The average results of BM model calculations for primary melts reconstructed from parental melts with $\mathrm{FeO}_{\mathrm{i}}=6.93$ wt $\%$ are $8 \pm 3.5 \%$ of melting of the 0.4 A-DMM +0.6 E-DMM source, while with $\mathrm{FeO}_{\mathrm{i}}=8.93$ wt $\%-10.3 \pm 4.3 \%$ of melting of the 0.6 A-DMM + 0.4 E-DMM source. The AFM model gives $13.9 \pm 5.1 \%$ of melting of the E-DMM source at $\mathrm{FeO}_{\mathrm{i}}=6.93 \mathrm{wt} \%$ and $17 \pm 5.4 \%$ of melting of the $0.9 \mathrm{E}-\mathrm{DMM}+0.1 \mathrm{PM}$ source at $\mathrm{FeO}_{\mathrm{i}}=8.93 \mathrm{wt} \%$. Consequently, the errors which could be expected from the uncertainties of FeOi are $\sim 10-11 \%$ for melting degrees and less than $10 \%$ for the mix of model mantle compositions for both AFM and BM models. Thus, it could be concluded that in our case even a serious error in the estimation of $\mathrm{FeO}_{\mathrm{i}}$ does not critically affect the results of mantle melting modeling.

\section{Source Composition Variations}

Our modeling indicates that the source composition is on average enriched by trace elements relative to A-DMM. Even the lower estimate provided by the BM model shows that it should occupy an intermediate position between A-DMM and E-DMM while the AFM model shows the upper estimate, which is close to E-DMM. The wide range of estimated source compositions for individual melts (Fig. 4a) could seem unusual, however, such an observation is not unique in
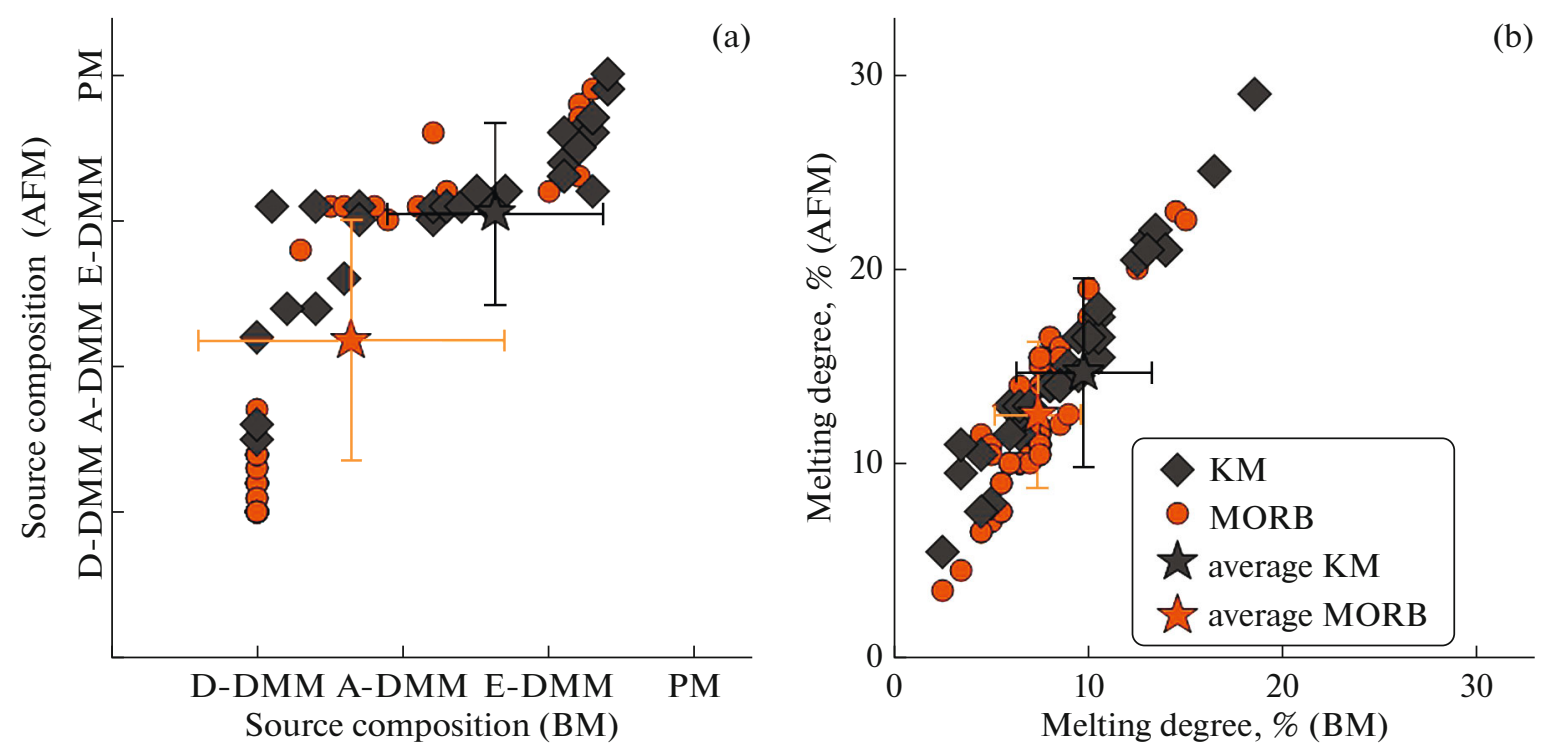

Fig. 4. Source composition and melting degrees of the primary melts of olivine-phyric rocks of Kamchatsky Mys and MORB (Jenner, O'Neill, 2012) following BM and AFM models. 
primitive melt inclusions. Lots of studies showed that primitive melt inclusions could preserve the information about primary source heterogeneity, which is lost upon further melt mixing (e.g., Sides et al., 2014; Sobolev, 1996; Yaxley et al., 2004).

At the same time, estimations of the source composition obtained for the set of primitive MORB glasses (Jenner, O’Neill, 2012) also vary in a wide range, however, on average they closely correspond to A-DMM (Fig. 4).

\section{Estimations of Melting Degrees}

We can compare our estimations of melting degrees, which are based on the content of trace elements, with, for example, major elements-based estimation, which could be done using PRIMELT3 MEGA software (Herzberg and Asimow, 2015). For BM and AFM models this algorithm gives $14.3 \pm 5.6 \%$ and $13.2 \pm 5.1 \%$, respectively, which matches our trace elements-based estimations within error. However, estimations of melting degrees obtained for individual melt compositions by these two methods have no correlation with each other, which could be explained by a much stronger influence of $\mathrm{FeO}_{i}$ on the results of major elements-based estimation. For example, a change of $\mathrm{FeO}_{\mathrm{i}}$ by $1 \mathrm{wt} \%$ upward or downward would result in a $\sim 45-60$ rel \% change of this major element-based estimation of melting degree. Two main conclusions can be drawn if we assume that both of these methods of melting degree estimation are correct: (1) our previous estimation of $\mathrm{FeO}_{\mathrm{i}}$ as $7.93 \mathrm{wt} \%$ is close to the true average value of the initial $\mathrm{FeO}$ content in studied melts; (2) comparison of major and minor elementbased methods of melting degree estimation could be used as an independent method for estimation of $\mathrm{FeO}_{\mathrm{i}}$ in primitive melts.

Average values of melting degrees estimated for olivine-phyric rocks from Kamchatsky Mys are slightly higher than similar estimations for primitive MORB glasses (Fig. 4). Relatively high melting degrees were also estimated for other rocks from Kamchatsky Mys ophiolites earlier (Batanova et al., 2014; Portnyagin et al., 2009). Portnyagin et al. (2009) concluded that basalts from the southeastern part of the Kamchatsky Mys are the result of $20 \%$ of nearly fractional melting on the base of the study of Cr-spinel hosted melt inclusions. One of the main feature of their samples was the abundance of ultra-depleted melt inclusions, which were interpreted as the final melt fractions produced in an upwelling mantle column (close to model infinitesimal melt fractions at $20 \%$ of fractional melting) (Portnyagin et al., 2009). The composition of these melts cannot be explained within our model because even the highest melting degrees of the most depleted endmember could not reproduce such depletion in highly incompatible trace elements. However, their compositions could be explained by $5-10 \%$ of the second-stage melting of the mantle source (Duncan and Green, 1980; Sobolev and Shimizu, 1993). In this case these ultra-depleted melts can be considered as just a result of melting more depleted sources than we used in our modeling.

Batanova et al., (2014) investigated the geochemical characteristics of minerals from peridotites of Kamchatsky Mys ophiolites and also concluded that they reflect anomalously high degrees of melting (from 8 to more than 22\%).

Both the reconstructed melts of volcanic rocks (this work; Portnyagin et al., 2009) and minerals from peridotites (Batanova et al., 2014) have characteristic Sr-anomalies; positive in the case of melts and negative in the case of minerals from peridotites. This fact allows us to conclude that rocks of the Kamchatsky Mys ophiolites have close genetic relations.

Portnyagin et al., (2009) as well as Batanova et al., (2014) have interpreted high melting degrees as evidence of high mantle potential temperature $\left(\mathrm{Tp}>1400^{\circ} \mathrm{C}\right)$, which could have been caused by proto-Hawaiian plume proximity. Our data contradict this interpretation because mantle potential temperature estimated for primary melts of olivine-phyric rocks from Kamchatsky Mys could be estimated as $\sim 1354 \pm 9.2^{\circ} \mathrm{C}$ (using PRIMELT3 MEGA software (Herzberg and Asimow, 2015)), which corresponds to an average $T \mathrm{p}$ for MORB mantle (Herzberg et al., 2007). Thus, elevated melting degrees at average MORB mantle potential temperature estimated for rocks of Kamchatsky Mys could have been caused either by elevated water content in the mantle source or low pressure of melting. On the one hand, we cannot prove that water content in the source was not elevated relatively to the typical MORB mantle, however, on the other hand, we have not found any geochemical signs of its elevated content (Korneeva et al., 2020). Thus, we assume that elevated mantle decompression speed, which causes lower pressure of melting, is the most plausible interpretation of the observed features of Kamchatsky Mys ophiolites. This process can also explain the $\mathrm{Sr}$ anomalies in Kamchatsky Mys rocks, because, in case of melting within the plagioclase stability field, plagioclase should have been the first phase to melt completely (e.g., Jaques and Green, 1980) and it should have been reflected in elevated $\mathrm{Sr}$ content in resulting melts.

Another feature of olivine-phyric rocks from Kamchatsky Mys, which could be explained by low melting pressure, is their early sulfide saturation (Korneeva et al., 2020; Savelyev et al., 2018). Sulfur concentration at sulfide saturation (SCSS) has negative dependence from pressure according to most modern models (e.g., Ariskin et al., 2018; Smythe et al., 2017), and thus primitive MORB melts should be substantially undersaturated by sulfur upon reaching Earth's surface (e.g., Li and Ripley, 2005). Consequently, the melt formed at a lower pressure than average MORB should 
reach the sulfide saturation at a lower degree of fractionation.

\section{CONCLUSIONS}

Our modeling of possible variations of chemical composition and melting degree of the source of olivine-phyric rocks from Kamchatsky Mys allows us to draw the following conclusions:

BM and AFM models allow us to describe the composition of primary melts of olivine-phyric rocks from Kamchatsky Mys with the same reliability on average. It does not allow us to conclude which of these mechanisms was closer to the true one in this case.

The source composition shows substantial chemical heterogeneity. Variations of its trace elements contents could have varied from D-DMM to 0.5 E-DMM + $0.5 \mathrm{PM}$ according to the $\mathrm{BM}$ model and from $0.5 \mathrm{D}-\mathrm{DMM}+0.5 \mathrm{~A}-\mathrm{DMM}$ to $\mathrm{PM}$ according to the AFM model. The average sources compositions vary from $0.5 \mathrm{~A}-\mathrm{DMM}+0.5 \mathrm{E}-\mathrm{DMM}$ to $0.9 \mathrm{E}-\mathrm{DMM}+$ $0.1 \mathrm{PM}$.

The average melting degrees according to $\mathrm{BM}$ and AFM models are estimated as $9.1 \pm 3.8 \%$ and $15.4 \pm 5.2 \%$, respectively, which is slightly higher than those estimated for primitive MORB glasses (7.4 \pm $2.2 \%$ and $12.5 \pm 3.8 \%)$. At the same time, elevated melting degrees of the source of the studied olivinephyric rocks are in good agreement with estimations for other rocks from Kamchatsky Mys ophiolites.

The low pressure of mantle melting caused by relatively high decompression speed could explain higher melting degrees of the Kamchatsky Mys rocks, their Sr-anomalies, and early saturation in sulfide.

\section{ACKNOWLEDGMENTS}

We are grateful to M.V. Portnyagin (Vernadsky Institute of Geochemistry and Analytical Chemistry, Russian Academy of Sciences) for useful comments on the earliest draft of the paper and V.S. Kamenetsky (University of Tasmania) for review, which allowed us to substantially improve the quality of the paper.

\section{FUNDING}

This study was funded by the Russian Science Foundation grant no. 16-17-10145.

\section{OPEN ACCESS}

This article is distributed under the terms of the Creative Commons Attribution 4.0 International Public License (http://creativecommons.org/licenses/by/4.0/), which permits unrestricted use, distribution, and reproduction in any medium provided you give appropriate credit to the original author(s) and the source, provide a link to the Creative Commons license, and indicate if changes were made.

\section{SUPPLEMENTARY INFORMATION}

The online version contains supplementary material available at https://doi.org/10.1134/S0869591121010045.

\section{REFERENCES}

Ariskin, A.A., Bychkov, K.A., Nikolaev, G.S., and Barmina, G.S., The COMAGMAT-5: modeling the effect of FeNi sulfide immiscibility in crystallizing magmas and cumulates, J. Petrol., 2018, vol. 59, no. 2, pp. 283-298.

Avdeiko, G.P., Savelyev, D.P., Palueva, A.A., and Popruzhenko, S.V., Evolution of the Kurile-Kamchatkan volcanic arcs and dynamics of the Kamchatka-Aleutian junction, Volcanism and Subduction: The Kamchatka Region, Eichelberger, J., Gordeev, E., Izbekov, P., Kasahara M., and Lees, J., Eds., Am. Geophys. Union, 2007, pp. 37-55.

Batanova, V.G., Lyaskovskaya, Z.E., Savelieva, G.N., and Sobolev, A.V., Peridotites from the Kamchatsky Mys: evidence of oceanic mantle melting near a hotspot, Russ. Geol. Geophys., 2014, vol. 55, no. 12, pp. 1395-1403.

Danyushevsky, L.V., Della-Pasqua, F.N., and Sokolov, S., Re-equilibration of melt inclusions trapped by magnesian olivine phenocrysts from subduction-related magmas: petrological implications, Contrib. Mineral. Petrol., 2000, vol. 138 , no. 1, pp. 68-83.

Danyushevsky, L.V. and Plechov, P., PETROLOG3: integrated software for modeling crystallization processes, Geochem. Geophys. Geosys., 2011, vol. 12, pp. 1-32.

Dick, H.J.B., Abyssal peridotites, very slow spreading ridges and ocean ridge magmatism, Magmatism in the Ocean Basins, Sounders A.D. and Norry, M.J., Geol. Soc. Spec. Publ., London, 1989, vol. 42, P. 71-105

Duncan, R. and Green, D.H., Role of multistage melting in the formation of oceanic crust, Geology, 1980, vol. 8, no. 1, pp. 22-26.

Gast, P.W., Trace element fractionation and the origin of tholeiitic and alkaline magma types, Geochim. Cosmochim. Acta, 1968, vol. 32, no. 10, pp. 1057-1086.

Herzberg, C., Asimow, P.D., Arndt, N., et al., Temperatures in ambient mantle and plumes: constraints from basalts, picrites, and komatiites, Geochem. Geophys. Geosys., 2007, vol. 8, pp. 1-34.

Herzberg, C. and Asimow, P.D., PRIMELT3 MEGA.XLSM software for primary magma calculation: peridotite primary magma $\mathrm{MgO}$ contents from the liquidus to the solidus, Geochem. Geophys. Geosys., 2015, vol. 16, no. 2, pp. 563-578.

Jaques, A.L. and Green, D.H., Anhydrous melting of peridotite at $0-15$ kbar pressure and the genesis of tholeiitic basalts, Contrib. Mineral. Petrol., 1980, vol. 73, pp. 287-310.

Jenner, F.E. and O'Neill, H.S.C., Analysis of 60 elements in 616 ocean floor basaltic glasses, Geochem. Geophys. Geosys., 2012, vol. 13, no. 2, pp. 1-11.

Khotin, M.Yu. and Shapiro, M.N., Ophiolites of the Kamchatsky Mys Peninsula, Eastern Kamchatka: structure, composition, and geodynamic setting, Geotectonics, 2006, vol. 40, no. 4, pp. 297-324.

Konstantinovskaia, E.A., Arc-continent collision and subduction reversal in the Cenozoic evolution of the Northwest Pacific: an example from Kamchatka (NE Russia), Tectonophysics, 2001, vol. 333, no. 1, pp. 75-94. 
Korneeva, A.A., Nekrylov, N., Kamenetsky, V., et al., Composition, crystallization conditions and genesis of sulfide-saturated parental melts of olivine-phyric rocks from Kamchatsky Mys (Kamchatka, Russia), Lithos, 2020, vol. 370-371, p. 105657.

Krasnova, E.A., Portnyagin, M.V., Silantyev, S.A., et al., Two-stage evolution of mantle peridotites from the Stalemate Fracture Zone, Northwestern Pacific, Geochem. Int., 2013, vol. 51, no. 9, pp. 683-695.

Li, C.S. and Ripley, E.M., Empirical equations to predict the sulfur content of mafic magmas at sulfide saturation and applications to magmatic sulfide deposits, Mineral. Deposita, 2005, vol. 40, no. 2, pp. 218-230.

Liang, Y. and Liu, B., Simple models for disequilibrium fractional melting and batch melting with application to REE fractionation in abyssal peridotites, Geochim. Cosmochim. Acta, 2016, vol. 173, pp. 181-197.

McDonough, W.F. and Sun, S.S., The composition of the Earth, Chem. Geol., 1995, vol. 120, nos. 3-4, pp. 223-253.

Mironov, N.L. and Portnyagin, M.V., Coupling of redox conditions of mantle melting and copper and sulfur contents in primary magmas of the Tolbachinsky Dol (Kamchatka) and Juan de Fuca Ridge (Pacific Ocean), Petrology, 2018, vol. 26, no. 2, pp. 145-166.

Nekrylov, N., Portnyagin, M.V., Kamenetsky, V.S., et al., Chromium spinel in Late Quaternary volcanic rocks from Kamchatka: implications for spatial compositional variability of subarc mantle and its oxidation state, Lithos, 2018, vol. 322, pp. 212-224.

Popov, D.V., Nekrylov, N., Plechov, P.Yu., et al., Composition and conditions of formation of the parental melts of Jurassic dolerites of southwestern Crimea: evidence from melt inclusions in olivine phenocrysts, Petrology, 2017, vol. 25, no. 3, pp. 272-303.

Portnyagin, M.V., Savel'ev, D.P., and Khernle, K., Plumerelated association of Cretaceous oceanic basalts of Eastern Kamchatka: compositions of spinel and parental magmas, Petrology, 2005, vol. 13, no. 6, pp. 571-588.

Portnyagin, M., Hoernle, K., Plechov, P., et al., Constraints on mantle melting and composition and nature of slab components in volcanic arcs from volatiles $\left(\mathrm{H}_{2} \mathrm{O}, \mathrm{S}, \mathrm{Cl}\right.$, $\mathrm{F})$ and trace elements in melt inclusions from the Kamchatka arc, Earth Planet. Sci. Lett., 2007a, vol. 255, nos. 1-2, pp. 53-69.

Portnyagin, M., Bindeman, I., Hoernle, K., and Hauff, F., Geochemistry of primitive lavas of the Central Kamchatka Depression: magma generation at the edge of the Pacific Plate, Geophys. Monogr. Am. Geophys. Union, 2007b, vol. 172, pp. 1-41.

Portnyagin, M., Savelyev, D., Hoernle, K., et al., Mid-Cretaceous Hawaiian tholeiites preserved in Kamchatka, Geology, 2008, vol. 36, no. 11, pp. 903-906.
Portnyagin, M., Hoernle, K., and Savelyev, D., Ultra-depleted melts from Kamchatkan ophiolites: evidence for the interaction of the Hawaiian plume with an oceanic spreading center in the Cretaceous?, Earth Planet. Sci. Lett., 2009, vol. 287, nos. 1-2, pp. 194-204.

Savelyev, D.P., Plagioclase picrites in the Kamchatsky Mys Peninsula, Eastern Kamchatka, J. Volcanol. Seismol., 2014, vol. 8, no. 4, pp. 43-53.

Savelyev, D.P., Kamenetsky, V.S., Danyushevsky, L.V., et al., Immiscible sulfide melts in primitive oceanic magmas: evidence and implications from picrite lavas (eastern Kamchatka, Russia), Am. Mineral., 2018, vol. 103, no. 6, pp. 886-898.

Shaw, D.M., Trace element fractionation during anatexis, Geochim. Cosmochim. Acta, 1970, vol. 34, pp. 237-243.

Sides, I.R., Edmonds, M., Maclennan, J., et al., Eruption style at Kilauea Volcano in Hawaii linked to primary melt composition, Nat. Geosci., 2014, vol. 7, no. 6, pp. 464-469. Smythe, D.J., Wood, B.J., and Kiseeva, E.S., The s content of silicate melts at sulfide saturation: new experiments and a model incorporating the effects of sulfide composition, Am. Mineral., 2017, vol. 102, no. 4, pp. 795-803.

Sobolev, A.V., Melt inclusions in minerals as a source of principle petrological information, Petrology, 1996, vol. 4, no. 3, pp. 209-220.

Sobolev, A.V. and Shimizu, N., Ultra-depleted primary melt included in an olivine from the Mid-Atlantic ridge, Nature, 1993, vol. 363, no. 6425, pp. 151-154.

Stolper, E. and Newman, S., The role of water in the petrogenesis of Mariana trough magmas, Earth Planet. Sci. Lett., 1994, vol. 121, nos. 3-4, pp. 293-325.

Tobelko D.P., Portnyagin M.V., Krasheninnikov S.P., et al., Compositions and formation conditions of primitive magmas of the Karymsky volcanic center, Kamchatka: evidence from melt inclusions and trace-element thermobarometry, Petrology, 2019, vol. 27, no. 3, pp. 243-264.

Volynets, A.O., Churikova, T.G., Worner, G., et al., Mafic Late Miocene-Quaternary volcanic rocks in the Kamchatka back arc region: implications for subduction geometry and slab history at the Pacific-Aleutian junction, Contrib. Mineral. Petrol., 2010, vol. 159, no. 5, pp. 659-687.

Workman, R.K. and Hart, S.R., Major and trace element composition of the depleted MORB mantle (DMM), Earth Planet. Sci. Lett., 2005, vol. 231, nos. 1-2, pp. 53-72.

Yaxley, G.M., Kamenetsky, V.S., Kamenetsky, M., et al., Origins of compositional heterogeneity in olivine-hosted melt inclusions from the Baffin Island picrites, Contrib. Mineral. Petrol., 2004, vol. 148, no. 4, pp. 426-442.

Zou, H., Trace element fractionation during modal and nonmodal dynamic melting and open-system melting: a mathematical treatment, Geochim. Cosmochim. Acta, 1998, vol. 62 , no. 11 , pp. 1937-1945. 